\section{Variable Yield of Bell Pepper Established on Converted Perennial Pasture Fertilized According to Recommendations}

\author{
V.M. Russo ${ }^{1}$ and \\ B.W. Roberts ${ }^{2}$
}

Additional index words. soil $\mathrm{pH}$, soil depth, nitrogen, phosphorous, potassium

Summary. Soil conditions may not be adequate for uniform yields when perennial pasture is converted to vegetable production. This occurred with 'Pip' bell pepper (Capsicum annuum var. annuum L.) planted in a 0.17 -acre field 3 years after conversion from perennial pasture. Depths of the A-horizon and $\mathrm{pH}$ levels, as well as concentrations of $\mathrm{N}, \mathrm{P}$, and $\mathrm{K}$ were variable throughout the field when sampled after the last harvest. Marketable yields from plots established in the field ranged from 4.1 to 14.5 tons/acre. The A-horizon depth, soil $\mathrm{pH}$, and residual $\mathrm{N}, \mathrm{P}$, and $\mathrm{K}$ levels were correlated with yield at specific A-horizon depths and $\mathrm{pH}$ levels. An intensive soil-testing regime likely will be required so that nutrient levels can be maintained to support bell pepper production on soil converted from perennial pasture.

I $\mathrm{n}$ the southern plains, cow-calf operations are one of the major agricultural enterprises. A typical farm contains perennial pasture that has received limited amounts of fertilizer, lime, or tillage. In regions of the country with established intensive farming programs, perennial pastures often are rel-

${ }^{I}$ United States Department of Agriculture, Agricultural Research Service, South Central Agricultural Research Laboratory, POB 159, Lane, OK 74555..

${ }^{2}$ Wes Watkins Agricultural Research and Education Center, Oklahoma State University, POB 128 Lane, OK 74555 . egated to land of low productivity and are not well-suited for row-crop production. Quality of the land for pasture usage is generally not a concern because field records have shown that the soils can support pasture. Historically, land in the southern plains has been converted from other uses to pasture,

In recent years there has been increased interest in alternative agriculture, which often means that land previously used for cow-calf operations is now being used for vegetable production. With this change in farm enterprises, there is a corresponding change in soil management techniques that brings with it certain problems. Perennial pasture soils tend to be heterogeneous. Factors contributing to this condition include soil genesis and the type and extent of component cover plants and root distribution through the various horizons (Jenny, 1980). In addition, native chemical and physical soil characteristics, fertilizer application (West et al., 1989), and the amount of plant (Jenny, 1980) and animal (Barrow, 1967) organic material deposited annually contribute to the condition of perennial pasture soils. Soils in perennial pasture are in equilibrium with the plant cover. Soils newly converted from perennial pasture, including those amended with nutrients or lime in response to soil test results, may not be adequate immediately for vegetable production, as are those that have been in row crops for extended periods. Conversion of perennial pasture to vegetable production changes the established equilibrium and produces an environment that could be disturbed several times a year. The objective of this study was to document the variability in bell pepper yields in an area recently converted from perennial pasture, and to correlate the variations in crop yields with variations in soil physical and chemical characteristics. Understanding these processes can be of help to extension workers, field representatives, and consultants as they assist farmers attempting to convert their operations to include vegetables as cash crops.

The soil converted from pasture was a Bernow fine-loamy, siliceous, thermic Glossic Paleudalf soil, which has a sandy loam A-horizon depth to 15 inches overlaying a sandy clay loam layer that extends to 65 inches (Shingleton and Watterson, 1979). The $217 \times 36$-ft $(0.17$-acre $)$ field was covered with common bermudagrass [ Cynodon dactylon (L.) Pers.] and native prairie grasses prior to 1986 , when it was placed into vegetable production. In 1986, soil samples were taken at random by collecting $\approx 20$ subsamples, combining and mixing the subsamples, and analyzing a portion of the combined sample as described by Johnson (1985). Samples were analyzed by Oklahoma State Univ. (OSU) using routine procedures (McElreath and Johnson, 1990). Results produced by OSU and sent to producers report levels of $\mathrm{N}, \mathrm{P}, \mathrm{K}, \mathrm{pH}$, and soil buffering index and include recommendations for regulating $\mathrm{pH}$ with dolomitic or calcitic lime to assure the availability of other nutrients such as calcium or magnesium. Micronutrient availability for most crops grown in these soils is not a problem if $\mathrm{pH}$ is appropriately adjusted. The $1986 \mathrm{pH}$ was 5.1 and lime at recommended rates (1.0 ton/ acre) was incorporated by moldboard plowing (to 12 inches) and discing (to 8 inches) during Oct. 1986. Dry beans

Table 1. Means and standoord deviations for postbarpest soil levels of $N, P$, and $K$ partitioned by A-borison dopth and $p H$.

\begin{tabular}{ccccc}
\hline \multirow{2}{*}{ Nutrient } & $\begin{array}{c}\text { A-horizon } \\
\text { depth (inches) }\end{array}$ & \multicolumn{4}{c}{$\mathbf{p H}$} \\
\cline { 3 - 5 } & & \multicolumn{4}{c}{ Soil nutrient level (bb/acre) by pH lepel } \\
$\mathrm{N}$ & $\leq 10.25$ & $21.4 \pm 26.4$ & $7.1 \pm 4.0$ & $6.2 \pm 2.6$ \\
& $\geq 10.25$ to $<13.25$ & $13.4 \pm 13.6$ & $9.8 \pm 5.5$ & $7.1 \pm 2.4$ \\
& $\geq 13.25$ & $6.2 \pm 2.0$ & $6.2 \pm 2.0$ & $15.2 \pm 14.6$ \\
$\mathrm{P}$ & $\leq 10.25$ & $46.4 \pm 34.4$ & $42.8 \pm 27.7$ & $55.3 \pm 59.0$ \\
& $\geq 10.25$ to $<13.25$ & $23.2 \pm 8.5$ & $32.1 \pm 8.7$ & $39.3 \pm 34.4$ \\
& $\geq 13.25$ & $25.0 \pm 15.3$ & $21.4 \pm 10.1$ & $20.5 \pm 7.5$ \\
$\mathrm{~K}$ & $\leq 10.25$ & $188.2 \pm 43.6$ & $156.1 \pm 24.9$ & $156.1 \pm 33.5$ \\
& $\geq 10.25$ to $<13.25$ & $161.5 \pm 45.8$ & $169.5 \pm 44.7$ & $135.6 \pm 27.6$ \\
& $\geq 13.25$ & $169.5 \pm 29.4$ & $132.9 \pm 24.1$ & $143.6 \pm 23.1$
\end{tabular}




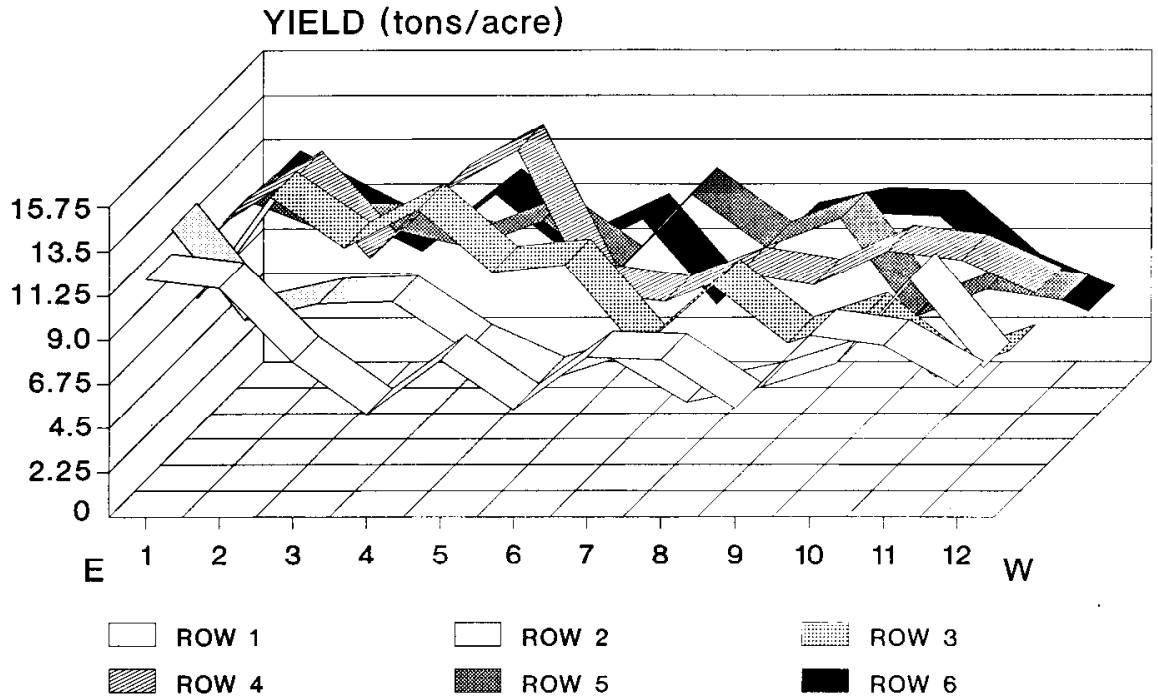

Fig. 1 . Yield for bell poppor in plots in rows 1-6. Numbers 1-12 on the x-axis mpresent tiers of plots in a row.

and snap beans were planted in 1987, followed by carrots in 1988. In Sept. 1988, soil $\mathrm{pH}$ was 5.7 and $62 \mathrm{lb} \mathrm{N} /$ acre, $44 \mathrm{lb}$ P/acre, and $141 \mathrm{lb}$ K/acre, respectively, were present. An additional 1.0 ton/acre of lime was applied and incorporated.

In Spring 1989, based on soil tests, $50 \mathrm{lb}$ N/acre, $22 \mathrm{lb}$ P/acre, and $83 \mathrm{lb}$ K/acre were applied uniformly preplant. Raised beds on 6-ft centers were formed in Apr. 1989. The experimental area included 72 plots (12 tiers of plots in each of six rows; Fig. 1), in addition to a guard row to the north and south. Plots were $12 \mathrm{ft}$ long and separated in length by a 6-ft alley. 'Pip' bell pepper plants were transplanted on 19 Apr. 1989 on 12 inches within rows and $6 \mathrm{ft}$ between rows. Rainfall supplied 19.5 inches of water and an additional 3 inches of water was supplied evenly to all plots by drip irrigation.

Marketable yields (US\#l or better) from each plot were determined from nine weekly harvests between 6 July and 31 Aug. 1989. After the final harvest, soil samples were obtained from the top 4 inches of each plot and analyzed in routine soil tests for $\mathrm{pH}$ and $\mathrm{N}, \mathrm{P}$, and $\mathrm{K}$ levels by OSU. The A-horizon depth was determined by removing 0.75 -inchdiameter soil cores on 18-inch intervals through the length of each plot. Within the plots, values of $\mathrm{pH}$ and A-horizon depth were found to be highly variable, and the plots were classified for partitioning according to soil $\mathrm{pH}$ and Ahorizon depth. Soil $\mathrm{pH}$ was chosen for partitioning because it affects nutrient availability to the plant (Devlin, 1969), and initial correlation analysis indicated that it affected yield significantly ( $P=$ 0.0001). The A-horizon depth was chosen for partitioning because it is a physical characteristic that is not easily manipulated. To establish the $\mathrm{pH}$ partitions, plots were grouped into three $\mathrm{pH}$ categories $(\leq \mathrm{pH} 5.5, \geq \mathrm{pH} 5.6$ to $<5.9$, and $\geq \mathrm{pH}$ 5.9) based on expected plant responses. Each $\mathrm{pH}$ categorywas further partitioned into three A-horizon depths (110.25 inches, $>10.25$ to $<13.25$ inches, and >13.25 inches). Each Ahorizon depth by $\mathrm{pH}$ partition had six to 11 observations, averaging nine, with 72 total observations. Yield information in the partitions was analyzed by backward stepwise regression. This is a computer-supported statistical method that examines all measured (independent) variables for effects and systematically removes variables until only those that best describe the observed effects re- main. This procedure is a product of the Statistical Analysis System (SAS, Cary, N.C.). The soil tests, taken after the last harvest, affirmed the variable nutrient availability in the field. It was found that levels of soil $\mathrm{N}$ were 3.0 to $77.6 \mathrm{lb} / \mathrm{acre}$ (avg. 9.9), soil $\mathrm{P}$ was 6.25 to $155.0 \mathrm{lb} /$ acre (avg. 30.4), and soil $\mathrm{K}$ was 80.3 to $241.7 \mathrm{lb} / \mathrm{acre}$ (avg. 142.4). The average soil $\mathrm{pH}$ was 5.6, ranging from 4.8 to 6.5; A-horizon depths averaged 7.9 inches and ranged from 3.8 to 19.7 inches. Means for $\mathrm{pH}$ and soil $\mathrm{N}, \mathrm{P}$, and $\mathrm{K}$ in the nine A-horizon depth $\times \mathrm{pH}$ partition cells are presented in Table 1 . The coefficients of variation for residual levels of both $\mathrm{N}$ and $\mathrm{P}$, across A-horizon depth $\times \mathrm{pH}$ partitions, ranged from $\approx 30 \%$ to $115 \%$. For residual levels of $K$, in the same partitions, coefficients ofvariation ranged from $16 \%$ to $28 \%$. The average plot yield was 8.4 tons/acre, with yields ranging from 4.1 to 14.5 tons/acre (Fig. 1). There was no clear correlation between yield and N, P, or Klevels in the field. Within partitions, no single factor was correlated consistently with yield. Depth of the A-horizon, $\mathrm{pH}$, and residual $\mathrm{K}$ levels were correlated strongly with yield-specific combinations of A-horizon depth and $\mathrm{pH}$ in plots (Table 2).

The heterogeneity of soil and nutrient levels within this field was the most critical factor affecting yield. Uniform tillage, liming, and fertilization over a 3-year period did not reduce variation in yield for bell pepper in a 0.17 -acre field. The addition of lime increased the average soil $\mathrm{pH}$, but $\mathrm{pH}$ values were not uniform across the field. Soil $\mathrm{pH}$ was correlated positively with crop yield. Factors causing $\mathrm{pH}$ variability in soil can be physical or chemical. Availability of N, P, and $\mathrm{K}$ is reduced at $\mathrm{pH}$ values below 6.0 (Brady,

Table 2. Variable(s) positipely (+) or negatipely (-) correlated witb yield and Prob $>F$ in soils partitioned for A-borizon doptb (incbes) and $P H$. Romopal of the pariable from the backward stepwise regression model was at Prob $>F=0.1000$.

\begin{tabular}{|c|c|c|c|}
\hline \multirow[b]{3}{*}{$\begin{array}{l}\text { A-horizon } \\
\text { depth (inches) }\end{array}$} & \multicolumn{3}{|c|}{ pH } \\
\hline & $\leq 5.5$ & $\geq 5.6$ to $<5.9$ & $\geq 5.9$ \\
\hline & $\begin{array}{c}\text { Variable, } \\
\text { correlation, }(\text { Prob }>\text { F) }\end{array}$ & $\begin{array}{c}\text { Variable, } \\
\text { correlation, }(\text { Prob }>\text { F) }\end{array}$ & $\begin{array}{c}\text { Variable, } \\
\text { correlation, }(\text { Prob }>\text { F) }\end{array}$ \\
\hline $\begin{array}{l}\leq 10.25 \\
\geq 10.25 \text { to }\end{array}$ & $\operatorname{Depth}^{z},(+),(0.0001)$ & Depth, $(+),(0.0001)$ & $\mathrm{K},(+),(0.0011)$ \\
\hline$<13.25$ & $\begin{array}{c}\mathrm{pH},(+),(0.0001) \\
\mathrm{N},(-),(0.0171)\end{array}$ & $\mathrm{pH},(+),(0.0001)$ & Depth, $(+),(0.0011)$ \\
\hline$\geq 13.25$ & $\begin{array}{c}\mathrm{pH},(+),(0.0040) \\
\mathrm{P},(+),(0.0530) \\
\mathrm{N},(-),(0.0570)\end{array}$ & $\mathrm{pH},(+),(0.0001)$ & $\mathrm{K}_{,}(+),(0.0001)$ \\
\hline
\end{tabular}


1984). Only about $25 \%$ of the plots were at or above this $\mathrm{pH}$ value. Although bell pepper is moderately tolerant to soil acidity (Lorenz and Maynard, 1988), the $\mathrm{pH}$ values from numerous individual plots were too low to support adequate bell pepper production. Routine soil sampling did not report accurately the low individual $\mathrm{pH}$ values.

The average yield for 'Pip' bell pepper at Lane, Okla., is 9.8 tons/acre (Oklahoma State Univ., 1989,1990), which is $\approx 13 \%$ more than the average of 8.5 tons/acre reported here. Based on figures reported by Lorenz and Maynard (1988), 8.5 tons/acre of pepper fruit would require $106 \mathrm{lb}$ N/acre, $7 \mathrm{lb} \mathrm{P/}$ acre, and $106 \mathrm{lb} \mathrm{K} / \mathrm{acre}$. The average soil concentrationsof $112 \mathrm{lb}$ N/acre, 66 lb P/acre, and $224 \mathrm{lb}$ K/acre (amount in soil preplant plus amount applied) should have supplied the nutrient needs of the pepper crop. Nutrient leaching is common on sandy soils (Earl and Jarry, 1977), but leaching does not explain the positive relationship between yield and A- horizon depth. Variation in levels of residual soil nutrients at different Ahorizon depths can explain some, but not all, of the difference in yields. The combined effects of $\mathrm{pH}$ and A-horizon depth could affect rhizosphere nutrient availability and uptake. Nutrients exert specific effects on plant development; these effects can be modified by combinations of A-horizon depth and $\mathrm{pH}$.

Standard deviations and coefficients of variation for residual levels of $\mathrm{N}, \mathrm{P}$, and $\mathrm{K}$ indicate that each plot had a unique nutrient level that was not estimated adequately by the soil test and that contributed to the variation in yield. Routine soil tests, as performed by OSU, assume that $\mathrm{pH}, \mathrm{N}, \mathrm{P}$, and $\mathrm{K}$, expressed as averages of those values, are the factors that are likely to limit crop production. These tests can mask large differences in available nutrients and $\mathrm{pH}$ within either large or small acreages. Three crop cycles passed between the initial liming and the final soil test, but there was still extreme variability in $\mathrm{pH}$ and nutrient concentrations within the small area of these plots. This project demonstrated that values obtained in a routine soil test were not sufficient to predict or prevent yield variability in nonuniform soils. If $\mathrm{pH}$ is at the proper level in southern plains soils, calcium and magnesium are nor limiting, and soils reports from OSU do not include this information.
As farm profit margins are reduced, fertilizer efficiency will be a key to farm survival. Maximum profits will exist only when crops receive sufficient, but not excessive, levels of all nutrients. If lime and fertilizer had been added uniformly to this field at a rate required to raise the most infertile plots to an optimum level of fertility, then other plots fertilized at the same rate would have received rates that were above the point of maximum economic return. The transition from perennial pasture to other cropping systems likely will be made more efficient if soils are prepared far in advance of planting high-value crops. Extensive deep tillage is needed to homogenize the soil plow layer. When soils in perennial pasture are converted to vegetable production, soil sampling should be conducted with a pattern that requires more samples/unit area than is normally recommended, and fertilization techniques should reflect the soil nutrient variability. Soils should be monitored closely for variations in $\mathrm{pH}$ and nutrient levels in order to have uniform yields across fields and to maximize profits.

\section{Literature Cited}

Barrow, N.J. 1967. Some aspects of the effects of grazing on the nutrition of pastures. J. Austral. Inst. Agr. Sci. 33:254-262.

Brady, N. C. 1984. The nature and properties of soils. Macmillan, New York.

Devlin, R.M. 1969. Plant physiology. Van Nostrand Reinhold, New York.

Earl, K.D. and W.A. Jarry. 1977 Water movement in bare and cropped soil under trickle emitters. II. Analysis of cropped soil experiments. Soil Sci. Soc. Amer. J. 41:856-861.

Jenny, H. 1980. The soil resource. Ecological Studies 37. Springer Verlag, New York.

Johnson, G. 1985. How to get a good soil sample. OSU Ext. Facts 2207.

Lorenz, O.A. and D.N. Maynard. 1988. Knott's handbook for vegetable growers. 3rd ed. WileyInterscience, New York.

McElreath, D.L. and G. V. Johnson. 1990. Soil, water, and forage analytical laboratory: Laboratory procedures manual. Okla. State Univ. Agron. Bul. 90-1.

Oklahoma State Univ. 1989. 1988 Vegetable trial report. Okla. State Univ. Hort. Bul. 89-1.

Oklahoma State Univ. 1990. 1989 Vegetable trial report. Okla. State Univ. Hort. Bul. 90-1.

Shingleton, L.C. and A. Watterson, Jr. 1979. Soil survey of Atoka County, Oklahoma. USDA, SCS, Okla. Agr. Expt. Sta.

West, C.P., A.P. Mallarino, W.F. Wedin, and D.B. Marx. 1989. Spatial variability of soil chemical properties in grazed pastures. Soil Sci. Soc. Amer. J. 53:784-789. 